\title{
Kualitas diet, kurang energi kronis (KEK), dan anemia pada pengantin wanita di Kabupaten Semarang
}

Fillah Fithra Dieny", Firdananda Fikri Jauharany, Deny Yudi Fitranti, A Fahmy Arif Tsani, Ayu Rahadiyanti, Dewi Marfu'ah Kurniawati, Hartanti Sandi Wijayanti

\begin{abstract}
Introduction: Pre-conception women are potential mothers or vulnerable groups who need special attention. The less of nutrients Intake than necessary can lead to nutritional problems such as Chronic Energy Deficiencyand nutritional anemia that have an impact on the next phase of life such as the risk of giving birth to babies with low birth weight (LBW), babies stunting, and growth disruption and development of the fetus / baby during pregnancy or after that.

Objective: To analyze the relationship between diet quality, chronic energy malnutrition status with anemia in the bride.

Methods: A cross-sectional study with 70 subjects who were brides aged 16-30 years. Selection of subjects with consecutive sampling method. Dietary quality data was measured through the Semi Quantitative Food Frequency Questionnaire (SQ-FFQ) and Diet Quality Index - International (DQI-I) forms, SEZ status assessed from body mass index (BMI) and upper arm circumference (LiLA). Anemia status was measured from hemoglobin levels, MCV, MCH, and MCHC. To examine the relationship between diet quality, chronic energy malnutrition, and anemia using a linear regression test.

Results: The subject aged 16-30 years, and $41.4 \%$ are still $<20$ years old. A total of 10 subjects (14.3\%) belonged to Chronic Energy Deficiency. Haemoglobin level measurements showed there were 8 subjects (11.4\%) who had low Hb levels, and 4 of them had anemia with microcytic hypychromic type which was characterized by low MCV, MCH and MCHC values. Based on the calculation of intake was known that 55 subjects (78.6\%) had a low quality diet. This study showed no relationship between diet quality and anemia, but the sub-components of diet quality were adequacy of protein intake $(p=0.007)$, iron intake $(p=$ $0.009)$ and upper arm circumference $(p=0.018)$ indicating a significant relationship with anemia (hemoglobin level) in the bride.

Conclusion: the less protein and iron intake and lower upper arm circumference associated with a decrease in the bride's hemoglobin level
\end{abstract}

Keywords: Anemia; chronic energy shortages; diet quality; preconception.

\section{ABSTRAK}

Pendahuluan: Wanita usia subur pra-nikah (masa pra-konsepsi) merupakan calon ibu atau kelompok rawan yang membutuhkan perhatian khusus. Asupan zat gizi yang kurang dari kebutuhan dapat menimbulkan masalah gizi seperti Kurang Energi Kronis (KEK) dan anemia defisiensi zat gizi yang berdampak pada fase kehidupan selanjutnya seperti berisiko melahirkan bayi dengan berat badan lahir rendah (BBLR), bayi mengalami stunting, dan terganggunya pertumbuhan dan perkembangan janin saat kehamilan maupun setelahnya.

Tujuan : Menganalisis hubungan antara kualitas diet, KEK, dan anemia pada pengantin wanita di kabupaten Semarang.

Metode: Penelitian cross-sectional dengan subjek 70calon pengantin wanita usia 16-30 tahun.Pemilihan subjek dengan metode consecutive sampling.Data kualitas diet diukur melalui form Semi Quantitative Food Frequency Questionnaire (SQ-FFQ) dan formulirDiet Quality Index - International (DQI-I), status KEK dinilai dari indeks massa tubuh (IMT) dan lingkar lengan atas (LiLA). Status anemia diukur dari kadar hemoglobin, MCV, MCH, dan MCHC. Untuk menguji hubungan antara kualitas diet, $K E K$, dan anemia menggunakan uji regresi linear.

Hasil: Rentang usia subjek 16-30 tahun, dan 41,4\% masih berusia < 20 tahun. Sebanyak 10 subjek (14,3\%) tergolong KEK. Pengukuran kadar Hb menunjukkan terdapat 8 subjek (11,4\%) memiliki kadar Hb yang rendah, dan 4 diantaranya memiliki anemia dengan tipe mikrositik hipikromik yang ditandai dengan rendahnya nilai MCV, MCH dan MCHC.. Hasil perhitungan asupan berdasarkan kebiasaan makan subjek, diketahui bahwa 55 subjek $(78,6 \%)$ memiliki kualitas diet rendah. Penelitian ini menunjukkan tidak ada hubungan kualitas diet dengan anemia, namun sub komponen kualitas diet yaitu kecukupan asupan protein $(p=0,007)$, asupan zat besi $(p=0,009)$, dan KEK berdasarkan lingkar lengan atas $(p=0,018)$ menunjukkan hubungan signifikan dengan anemia (kadar haemoglobin) pada pengantin wanita

Simpulan: semakin kurang asupan protein dan zat besi serta rendahnya lingkar lengan atas berhubungan signifikan dengan menurunnya kadar hemoglobin pengantin wanita

Kata kunci: Anemia; kekurangan energi kronis; kualitas diet; prakonsepsi

Departemen Ilmu Gizi, Fakultas Kedokteran, Universitas Diponegoro, Jl. Prof. Soedarto, S.H. Tembalang, Kota Semarang, Jawa Tengah, Indonesia

*Korespondensi : Email : fillahdieny@gmail.com 


\section{PENDAHULUAN}

Wanita usia subur (WUS) didefinisikan sebagai wanita yang berada dalam periode usia dewasa awal antara 15-49 tahun tanpa memperhitungkan status perkawinannya. Wanita memiliki peran penting dalam penentu kualitas sumber daya manusia, karena wanita memiliki peran dalam kehamilan dan melahirkan keturunan.Wanita usia subur pra-nikah (masa prakonsepsi) merupakan calon ibu atau kelompok rawan yang membutuhkan perhatian khusus. Namun, angkaterjadinya masalah gizi pada wanitadi Indonesia masih tinggi. Masalah gizi yang sering dialami adalah Kurang Energi Kronis (KEK) dan anemia gizi. ${ }^{1}$

Asupan energi dan protein yang tidak mencukupi pada ibu hamil dapat menyebabkan KEK. Ibu hamil dengan KEK akan berisiko melahirkan bayi dengan berat badan lahir rendah (BBLR), dan jika tidak ditangani dengan baik akan berisiko mengalami stunting. Kondisi lain yang banyak terjadi pada ibu hamil adalah anemia, terutama anemia defisiensi besi. Apabila wanita sudah mengalami anemia, maka akan memiliki risiko keguguran, kematian janin, kelahiran prematur, perdarahan serta kematian ibu dan bayiSelain itu, anemia dapat mempengaruhi pertumbuhan dan perkembangan janin/bayi saat kehamilan maupun setelahnya. Diperkirakan 41,8\% ibu hamil di seluruh dunia mengalami anemia, setengahnya disebabkan kekurangan zat besi. ${ }^{1}$

Berdasarkan data Riset Kesehatan Dasar (Riskesdas) tahun2013, prevalensi anemia di Indonesia masih cukup tinggi. Anemia pada remaja wanitasebesar $26,50 \%$, wanita usia subur $26,9 \%$, ibu hamil $40,1 \%$ dan anak balita $47,0 \% .^{2}$ Selain itu, prevalensi anemia defisiensi besi pada wanita usia subur di Kota Semarang menunjukkan peningkatan dari $23,40 \%$ menjadi $25,12 \%$ pada tahun 2005. ${ }^{3}$ Menurut penelitian yang dilakukan oleh Asyumdah (2016) di Puskesmas Sumowono Kabupaten Semarang, didapatkan prevalensi ibu hamil dengan kadar $\mathrm{Hb}<11$ gr/dl sebanyak 59,7\%. ${ }^{4}$ Salah satu indikator yang menentukan anemia terutama anemia zat gizi besi ditunjukkan dengan kadar hemoglobin. ${ }^{11}$ Pembentukan hemoglobin berhubungan dengan interaksi beberapa zat gizi, diantaranya energi, protein, vitamin $\mathrm{A}$, vitamin $C$, vitamin $B_{2}$, Vitamin $B_{6}$, vitamin $B_{12}$, zat besi, seng dan asam folat.

Anemia memiliki dampak yang cukup signifikan pada fase sebelum atau selama kehamilan.Anemia dapat berkontribusi pada kematian ibu dan janin. Berdasarkan profil kesehatan Provinsi Jawa Tengah tahun 2014, angka kematian ibu mengalami peningkatan jika dibandingkan dari tahun 2010 hingga 2014 sebesar $118,62 / 100.000$ kelahiran hidup. Kematian pada waktu nifas memiliki prevalensi paling tinggi yaitu sebesar $57,95 \%$, kematian pada waktu hamil sebesar $27 \%$ dan saat persalinan sebesar $15,05 \% .{ }^{6}$ Di Semarang, Angka
Kematian Ibu (AKI) tahun 2011 mengalami peningkatan dibandingkan tahun $2010 .^{7}$ Anemia sebelum atau selama kehamilan juga berdampak terhadap risiko kelahiran bayi dengan BBLR. Di Jawa Tengah presentase bayi dengan BBLR tahun 2006 sebesar 1,78\%. Pada tahun 2015, diketahui jumlah kasus bayi dengan berat badan lahir rendah (BBLR) di kabupaten Semarang sebesar $4,7 \%$. $^{8}$

Permasalahan gizi tersebut sebenarnya dapat ditentukan berdasarkan kesehatan dan status gizi ibu yang dipantau jauhsebelum hamil, yaitu pada masasedang mempersiapkan kehamilan.Salah satu orang yang berperan dalam masa itu adalah calon pengantin wanita (CPW) atau masa pra-konsepsi.Kebutuhan zat gizi pada masa ini penting karena calon pengantin wanita merupakan kelompok wanita yang akan mempersiapkan kehamilan dan menyusui.Calon pengantin wanita rentan menderita anemia gizi terutama besi dan asam folat dikarenakan mengalami masalah yang dialami wanita usia subur, seperti mengalami menstruasi setiap bulannya yang kehilangan darah sekitar 0-48 mg per hari (tergantung pada aliran menstruasi), kurang asupan zat gizi, infeksi parasit seperti malaria,kecacingan serta mayoritas WUS menjadi angkatan kerja. ${ }^{1,3,5}$

Program pemerintah untuk penanggulangan anemia pada calon pengantin wanita yaitu SUSCATIN (kursus calon pengantin) di KUA yang diselenggarakan Badan Penasihatan, Pembinaan, dan Pelestarian Perkawinan (BP4) masih belum efektif disebabkan kurangnya minat calon pengantin untuk datang karena belum adanya peraturan yang mewajibkan untuk datang. ${ }^{9}$ Disisi lain, materi yang dimuat belummenjelaskan terkait gizi pada wanita usia subur (pra-konsepsi). Selain itu, dalam Buku Saku Kesehatan Reproduksi dan Seksual bagi Calon Pengantin yang diterbitkan oleh Kementerian Kesehatan RI, pada bab persiapan pra-nikah, sudah terdapat persiapan gizi untuk menanggulangi anemia defisiensi besi serta folat. Namun, pada kenyataannya, di KUA maupun Puskesmas belum memberikan edukasi gizi pra-nikah kepada calon pengantin, sehingga calon pengantin masih sedikit yang memiliki pengetahuan gizi yang cukup. ${ }^{10}$

Berdasarkan profil kesehatan Kabupaten Semarang tahun 2012,KecamatanSumowono merupakan daerah dengan prevalensi angka kematian bayi (AKB) dan kematian ibu (AKI) yang paling tinggi diantara 26 daerah lainnya di Kabupaten Semarang dari tahun 2009 - 2014. Sumowono juga merupakan daerah dengan angka kejadian BBLR tinggi. Berdasarkan hasil penelitian sebelumnya, pada bulan Januari-Desember tahun 2015 bayi dengan berat lahir rendah sebanyak 34 kasus $(10,30 \%)$ dari 330 kelahiran hidup. ${ }^{4}$ Sejalan dengan itu, anemia merupakan salah satu penyakit terkait gizi dengan urutan ke 5 dari 10 penyakit yang sering terjadi di Desa Sumowono. ${ }^{12}$ 
Peningkatan status gizi calon pengantin terutama wanita, melalui penanggulangan KEK (Kekurangan Energi Kronis) dan anemia gizi besi serta defisiensi asam folat harus dilakukan, karena calon pengantin wanita dekat hubungannya dengan kehamilan dan menyusui. Kondisi kesehatan yang baik selama kehamilan dan menyusui tersebut salah satunya ditentukan oleh kualitas diet calon pengantin wanita sebelum menikah. Hingga saat ini belum terlalu banyak peneliti yang meneliti bagaimana hubungan kualitas diet, status gizi dan status anemia pada calon pengantin wanita. Berdasarkan latar belakang tersebut peneliti tertarik untuk menganalisis hubungan kualitas diet, status KEK, dan status anemia pada calon pengantin wanita di Kabupaten Semarang.

\section{BAHAN DAN METODE}

Penelitian ini merupakan penelitian observasional dengan desain cross-sectional yang dilakukan pada bulan November 2017-Agustus 2018. Populasi target penelitian ini adalah calon pengantin wanita berusia 1630 tahun. Sementara populasi terjangkau penelitian ini adalah calon pengantin wanita berusia16-30 tahun yang terdaftar di KUA Kecamatan Sumowono, Kabupaten Semarang pada bulan November 2017-Februari 2018.Setelah dilakukan perhitungan, besar sampel untuk penelitian ini sebanyak 61 subjek dan untuk mengantisipasi adanya drop out maka perlu dilakukan koreksi sebesar 10\% sehingga jumlah sampel minimum menjadi 68 subjek. Cara pemilihan sampel atau metode sampling dilakukan dengan cara consecutive sampling.

Kriteria inklusi pada penelitian ini adalah merupakan calon wanita yang terdaftar di KUA atau WUS di Kecamatan Sumowono, Kabupaten Semarang yang berusia 16-30 tahun; tidak sedang mengalami menstruasi; tidak sedang sakit kronis atau dalam perawatan dokter; tidak merokok; dan bersedia mengisi formulir informasi dan pernyataan kesediaan sebagai subjek penelitian. Kriteria eksklusi pada penelitian ini yaitu mengundurkan diri dari subjek penelitian; atau meninggal selama penelitian berlangsung. Berdasarkan kriteria inklusi dan eksklusi didapatkan jumlah sampel sebanyak 70 subjek.

Variabel terikat pada penelitian ini adalah status anemia yang dilihat dari kadar hemoglobin. Kadar normal hemoglobin pada wanita dewasa adalah 12-16 $\mathrm{g} / \mathrm{dl} .{ }^{13}$ Selain dilihat dari kadar $\mathrm{Hb}$, status anemia juga dilihat melalui pengukuran kadar Mean Corpuscular Volume (MCV), Mean Corpuscular Hemoglobin $(\mathrm{MCH})$, dan Mean Corpuscular Hemoglobin Concentration (MCHC). Kadar normal MCV adalah 80$100 \mathrm{fL}$, kadar normal $\mathrm{MCH}$ adalah 28-34 pg/sel, sedangkan kadar normal MCHC adalah 32-36 g/dL. Subjek dikatakan mengalami anemia defisiensi zat gizi apabila memiliki kadar $\mathrm{Hb}, \mathrm{MCV}, \mathrm{MCH}$, dan $\mathrm{MCHC}$ kurang dari normal. Status KEK dilihat dari pengukuran LiLA (Lingkar Lengan Atas) dan IMT (Indeks Masssa Tubuh). Subjek dikatakan berisiko KEK jika hasil pengukuran LiLA $<23,5 \mathrm{~cm}$ dan IMT $<18,5 \mathrm{~kg} / \mathrm{m}^{2}$. Calon pengantin wanita yang memiliki LiLA $<23,5 \mathrm{~cm}$ dan IMT $<18,5$ termasuk KEK $\left(17-18,4 \mathrm{~kg} / \mathrm{m}^{2} \quad\right.$ KEK tingkat I, $16-16,9 \mathrm{~kg} / \mathrm{m}^{2}$ KEK tingkat II, $<16 \mathrm{~kg} / \mathrm{m}^{2}$ KEK tingkat III). ${ }^{16}$

Variabel bebas pada penelitian ini adalah kualitas diet dan status KEK (Kekurangan Energi Kronis). Kualitas diet diukur dengan cara menilai konsumsimakanan menggunakan formulir Semi Quantitative Food frequencyquestionnaire(SQ-FFQ), yang kemudian dihitung skor kualitas dietnya menggunakan formulir Diet Quality Indexs International $\left(\right.$ DQI-I) ${ }^{14}$. Skor untuk masing-masing kategori (variasi, kecukupan, moderasi, keseimbangan keseluruhan) dijumlahkan, kemudian skor dari seluruh kategori ditotal sehingga total DQI-I bisa bervariasi mulai dari 0 sampai 100 (0 adalah skor terendah dan 100 merupakan skor tertinggi). Kualitas diet dianggap rendah apabila total skor $\leq 60 \%$ dari skor sempurna dan apabila skor $>60 \%$ dari skor sempurna maka kualitas dietnya tinggi. ${ }^{14,15}$

Analisis univariat untuk data numerik disajikan dalam bentuk rerata, standar deviasi, nilai maksimum, dan nilai minimum, sedangkan data kategorik disajikan dalam bentuk persentase. Untuk menganalisis hubungan kualitas diet dan status KEK dengan kadar hemoglobin digunakan uji regresi linear.

\section{HASIL}

\section{Karakteristik Subjek Penelitian}

Tabel 1 menunjukkan karakteristik subjek dalam penelitian ini. Sebanyak 70 subjek berpartisipasi dalam penelitian ini dengan rentang usia 16-30 tahun. Sebanyak 29 subjek $(41,4 \%)$ masih berusia $<20$ tahun. Terdapat 45 subjek $(64,3 \%)$ yang berstatus pekerja. Berdasarkan pengukuran IMT dan LiLA diketahui sebanyak 22 subjek $(31,4 \%)$ berisiko mengalami KEK dan sebanyak 10 subjek $(14,3 \%)$ telah mengalami KEK. Sebanyak 55 subjek $(78,6 \%)$ dalam penelitian ini memiliki kualitas diet yang tergolong rendah. Pada tabel 2, diketahui rentang skor kualiatas adalah 28-75 dan memiliki rerata $51,84 \pm 11,10$.

Tabel 3 menunjukkan sebanyak 8 subjek $(11,4 \%)$ menderita anemia yang ditunjukkan dari akdar $\mathrm{Hb}<12$ $\mathrm{mg} / \mathrm{dl}$. Pada subjek yang anemia, sebanyak 4 subjek $(50 \%)$ tergolong anemia mikrositik hipokromik, 3 subjek $(37,5 \%)$ mengalami anemia normositik hipokromik, dan sebanyak 1 subjek $(12,5 \%)$ mengalami anemia normositik normokromik. 
Tabel 1. Karakteristik Subjek Penelitian

\begin{tabular}{|c|c|c|}
\hline Kategori & Komponen & $\mathbf{n}(\%)$ \\
\hline \multirow[t]{3}{*}{ Usia } & Remaja madya (14-16 tahun) & $1(1,4)$ \\
\hline & Remaja akhir (17-20 tahun) & $28(40)$ \\
\hline & Dewasa awal (21-40 tahun) & $41(58,6)$ \\
\hline \multirow[t]{4}{*}{ Tingkat Pendidikan } & SD & $8(11,4)$ \\
\hline & SMP & $23(32,9)$ \\
\hline & SMA & $32(45,7)$ \\
\hline & Sarjana & $7(10)$ \\
\hline \multirow[t]{2}{*}{ Status Bekerja } & Bekerja & $45(64,3)$ \\
\hline & Tidak Bekerja & $25(35,7)$ \\
\hline \multirow[t]{3}{*}{ Status Gizi } & Normal (LiLA $\geq 23,5 \mathrm{~cm} ;$ IMT $\left.\geq 18,5 \mathrm{~kg} / \mathrm{cm}^{2}\right)$ & $38(54,3)$ \\
\hline & Berisiko $\left(\mathrm{LiLA}<23,5 \mathrm{~cm} ; \mathrm{IMT} \geq 18,5 \mathrm{~kg} / \mathrm{cm}^{2}\right)$ & $22(31,4)$ \\
\hline & KEK $\left(\right.$ LiLA $<23,5 \mathrm{~cm} ;$ IMT $\left.<18,5 \mathrm{~kg} / \mathrm{cm}^{2}\right)$ & $10(14,3)$ \\
\hline \multirow[t]{2}{*}{ Kualitas Diet (skor) } & Rendah $(\leq 60 \%)$ & $55(78,6)$ \\
\hline & Tinggi $(>60 \%)$ & $15(21,4)$ \\
\hline
\end{tabular}

Tabel 2. Nilai Minimum, Maksimum, Rerata, dan Standar Deviasi

\begin{tabular}{lrrr}
\hline Variabel & Min & Maks & Rerata \pm SD \\
\hline Usia & 16 & 30 & $21,81 \pm 3,25$ \\
Berat badan (kg) & 34,1 & 66,75 & $49,39 \pm 7,53$ \\
Tinggi badan (cm) & 136,5 & 167 & $151,44 \pm 4,82$ \\
IMT (kg/m ${ }^{\text {) }}$ & 15,6 & 32,8 & $21,54 \pm 3,33$ \\
Lingkar lengan (cm) & 17 & 30,7 & $23,97 \pm 2,84$ \\
Hematokrit & 26,1 & 46,4 & $39,43 \pm 3,35$ \\
Hemoglobin (g/dl) & 7,7 & 16 & $13,244 \pm 1,29$ \\
MCV (fL) & 55,7 & 95,2 & $84,07 \pm 6,45$ \\
MCH (pg/sel) & 17,9 & 31,8 & $28,19 \pm 2,52$ \\
MCHC (g/dl) & 29,5 & 36 & $33,52 \pm 1,06$ \\
Skor kualitas diet (skor) & 28 & 75 & $51,84 \pm 11,10$ \\
\hline
\end{tabular}

Tabel 3. Kategori Status Anemia Subjek Penelitian

\begin{tabular}{|c|c|c|}
\hline Kategori Anemia & Komponen & $\mathrm{n}(\%)$ \\
\hline \multicolumn{3}{|l|}{ Status Anemia } \\
\hline Anemia & Kadar $\mathrm{Hb}<12 \mathrm{mg} / \mathrm{dl}$ & $8(11,4)$ \\
\hline Tidak Anemia & Kadar $\mathrm{Hb} \geq 12 \mathrm{mg} / \mathrm{dl}$ & $62(88,6)$ \\
\hline Anemia Normositik Normokromik & Kadar $\mathrm{Hb}<12 \mathrm{mg} / \mathrm{dl} ; \mathrm{MCV} \geq 80 \mathrm{fL} ; \mathrm{MCH} \geq 28 \mathrm{pg} / \mathrm{sel}$ dan atau $\mathrm{MCHC} \geq 32 \mathrm{~g} / \mathrm{dL}$ & $1(12,5)$ \\
\hline Anemia Normositik Hipokromik & Kadar $\mathrm{Hb}<12 \mathrm{mg} / \mathrm{dl} ; \mathrm{MCV} \geq 80 \mathrm{fL} ; \mathrm{MCH}<28 \mathrm{pg} / \mathrm{sel}$ dan atau $\mathrm{MCHC}<32 \mathrm{~g} / \mathrm{dL}$ & $3(37,5)$ \\
\hline Anemia Mikrositik Hipokromik & Kadar $\mathrm{Hb}<12 \mathrm{mg} / \mathrm{dl} ; \mathrm{MCV}<80 \mathrm{fL} ; \mathrm{MCH}<28 \mathrm{pg} / \mathrm{sel}$ dan atau $\mathrm{MCHC}<32 \mathrm{~g} / \mathrm{dL}$ & $4(50)$ \\
\hline
\end{tabular}

\section{Karakteristik Kualitas Diet Subjek}

Tabel 4 menunjukkan gambaran kategori kualitas diet subjek. Dalam penelitian ini diketahui skor kualitas diet subjek berkisar antara 28-75 dengan rerata $51,84 \pm 11,10$ yang berarti kualitas diet pada subjek cenderung rendah. Nilai rerata skor kecukupan $22,41 \pm 6,328$ menunjukkan bahwa rata-rata subjek belum memenuhi kecukupan asupan sesuai rekomendasi. Sebanyak 59 subjek $(84,3 \%)$ kecukupan konsumsi sayuran tergolong kurang. Asupan zat besi dan kalsium subjek dalam penelitian ini tergolong rendah, yang menunjukkan bahwa asupan harian belum memenuhi angka kecukupan gizi (AKG). Sedangkan asupan buah, serat, dan protein subjek sebagian besar subjek sudah memenuhi kebutuhan asupan harian.
Pada Tabel 5 hasil skor variasi makanan subjek menunjukkan rentang skor 4-20 dengan rerata $15,74 \pm 3,602$. Rentang skor variasi yang cukup jauh menunjukkan perbedaaan jumlah kelompok makanan dan jenis sumber protein yang dikonsumsi oleh subjek. Skor moderasi digunakan untuk mengevaluasi asupan makanan dan zat gizi yang berhubungan dengan penyakit kronis dan perlu dibatasi. Rerata skor moderasi dalam penelitian ini adalah 12,73 $\pm 3,66$ yang menunjukkan skor moderasi subjek penelitian ini cenderung rendah. Skor moderasi yang rendah mengindikasikan adanya kecenderungan subjek untuk mengkonsumsi lemak, natrium dan makanan rendah gizi secara berlebihan. 
Tabel 4. Gambaran Kategori Kualitas Diet Subjek

\begin{tabular}{|c|c|c|}
\hline Kategori & Komponen & $\mathrm{n}(\%)$ \\
\hline \multicolumn{3}{|l|}{ Kecukupan } \\
\hline \multirow[t]{3}{*}{ Kelompok sayuran } & Baik ( $\geq 3-5$ sajian/hari) & $2(2,9)$ \\
\hline & Cukup $(<3-1.5$ sajian/hari) & $9(12,9)$ \\
\hline & Kurang $(<1.5$ sajian/hari) & $59(84,2)$ \\
\hline \multirow[t]{3}{*}{ Kelompok buah } & Baik ( $\geq 2-3$ sajian/hari) & $22(31,4)$ \\
\hline & Cukup (<2-1 sajian/hari) & $26(37,2)$ \\
\hline & Kurang (<1 sajian/hari) & $22(31,4)$ \\
\hline \multirow[t]{3}{*}{ Kelompok makanan pokok } & Baik ( $\geq 3-5$ sajian/hari) & $57(81,4)$ \\
\hline & Cukup $(<3-1.5$ sajian/hari) & $10(14,3)$ \\
\hline & Kurang ( $<1.5$ sajian/hari) & $3(4,3)$ \\
\hline \multirow[t]{3}{*}{ Serat } & Baik $(\geq 20-30 \mathrm{~g} /$ hari $)$ & $15(21,4)$ \\
\hline & Cukup $(<20-10 \mathrm{~g} /$ hari $)$ & $30(42,9)$ \\
\hline & Kurang $(<10$ gr/hari $)$ & $25(35,7)$ \\
\hline \multirow[t]{3}{*}{ Protein } & Baik $(\geq 15 \%$ energi/hari) & $22(31,4)$ \\
\hline & Cukup (< 15\%-7.5 energi/hari) & $48(68,6)$ \\
\hline & Kurang (< $7.5 \%$ energi/hari) & $0(0)$ \\
\hline \multirow[t]{3}{*}{ Besi } & Baik $(\geq 100 \%$ AKG mg/hari) & $3(4,3)$ \\
\hline & Cukup (<100-50\% AKG mg/hari) & $18(25,7)$ \\
\hline & Kurang $(<50 \%$ AKG mg/hari) & $49(70)$ \\
\hline \multirow[t]{3}{*}{ Kalsium } & Baik ( $\geq 100 \%$ AKG mg/hari) & $2(2,9)$ \\
\hline & Cukup (< 100-50\% AKG mg/hari) & $22(31,4)$ \\
\hline & Kurang (<50\% AKG mg/hari) & $46(65,7)$ \\
\hline \multirow[t]{3}{*}{ Vitamin C } & Baik ( $\geq 100 \%$ AKG mg/hari) & $45(64,3)$ \\
\hline & Cukup (<100-50\% AKG mg/hari) & $11(15,7)$ \\
\hline & Kurang $(<50 \%$ AKG mg/hari) & $14(20)$ \\
\hline \multicolumn{3}{|l|}{ Moderasi } \\
\hline \multirow[t]{2}{*}{ Total Lemak } & Baik ( $\leq 30 \%$ total energi/hari) & $17(24,3)$, \\
\hline & Lebih (> 30\% total energi/hari) & $53(75,7)$ \\
\hline \multirow[t]{2}{*}{ Lemak jenuh/SFA } & Baik $(\leq 10 \%$ total energi/hari) & $10(14,3)$ \\
\hline & Lebih (> $10 \%$ total energi/hari) & $60(85,7)$ \\
\hline \multirow[t]{2}{*}{ Kolesterol } & Baik $(\leq 300 \mathrm{mg} /$ hari $)$ & $44(62,9)$ \\
\hline & Lebih (> $300 \mathrm{mg} / \mathrm{hari})$ & $26(37,1)$ \\
\hline \multirow[t]{2}{*}{ Natrium } & Baik ( $\leq 2400 \mathrm{mg} / \mathrm{hari})$ & $65(92,9)$ \\
\hline & Lebih (> 2400 mg/hari) & $5(7,1)$ \\
\hline \multirow[t]{2}{*}{ Makanan tidak berkalori } & Baik $(\leq 10 \%$ total energi/hari) & $22(31,4)$ \\
\hline & Lebih (> 10\% total energi/hari) & $48(68,6)$ \\
\hline \multicolumn{3}{|l|}{ Variasi } \\
\hline \multirow[t]{5}{*}{ Semua Kelompok Makanan } & 5 kelompok makanan/hari & $16(22,9)$ \\
\hline & 4 kelompok makanan/hari & $29(41,4)$ \\
\hline & 3 kelompok makanan/hari & $15(21,4)$ \\
\hline & 2 kelompok makanan/hari & $5(7,1)$ \\
\hline & 1 kelompok makanan/hari & $5(7,1)$ \\
\hline \multirow[t]{3}{*}{ Kelompok Protein } & Baik ( $\geq 3$ sumber berbeda/hari) & $66(94,3)$ \\
\hline & Cukup ( 2 sumber berbeda/hari) & $3(4,3)$ \\
\hline & Kurang ( $\leq 1$ sumber/hari) & $1(1,4)$ \\
\hline \multicolumn{3}{|l|}{ Keseimbangan } \\
\hline \multirow[t]{4}{*}{ Rasio makronutrien } & Baik (55-65: 20-15: 15-25) & $4(5,7)$ \\
\hline & Cukup (52-68: 9-16: 13-27) & $4(5,7)$ \\
\hline & Cukup (50-70: 8-17: 12-30) & $8(11,5)$ \\
\hline & Kurang (Lainnya) & $54(77,1)$ \\
\hline \multirow[t]{3}{*}{ Rasio asam lemak } & Baik $(\mathrm{P} / \mathrm{S}=1-1,5$ dan $\mathrm{MS}=1-1,5)$ & $0(0)$ \\
\hline & Cukup $(\mathrm{P} / \mathrm{S}=0,8-1,7$ dan $\mathrm{MS}=0,8-1,7)$ & $4(5,7)$ \\
\hline & Kurang (Lainnya) & $66(94,3)$ \\
\hline
\end{tabular}


Tabel 5. Nilai Minimum, Maksimum, Rerata, dan Standar Deviasi Data Kualitas Diet Subjek

\begin{tabular}{|c|c|c|c|}
\hline Variabel & Min & Maks & Rerata \\
\hline Variasi (skor) & 4 & 20 & $15,74 \pm 3,602$ \\
\hline Semua kelompok makanan (kelompok makanan/hari) & 1 & 5 & $3,66 \pm 1,128$ \\
\hline Sumber protein (jenis/hari) & 1 & 6 & $5,67 \pm 0,912$ \\
\hline Kecukupan (skor) & 11 & 38 & $22,41 \pm 6,328$ \\
\hline Kelompok sayuran (porsi/hari) & 0 & 4 & $0,8 \pm 0,758$ \\
\hline Kelompok buah (porsi/hari) & 0 & 12 & $1,864 \pm 2,048$ \\
\hline Kelompok makanan pokok (porsi/hari) & 1 & 7 & $3,93 \pm 1,51$ \\
\hline Serat (g/hari) & 2 & 60,1 & $14,55 \pm 20,04$ \\
\hline Protein (g/hari) & 19,9 & 191 & $68,03 \pm 34,71$ \\
\hline Zat besi (mg/hari) & 1,7 & 32,8 & $11,21 \pm 6,35$ \\
\hline Kalsium (g/hari) & 41,1 & 1505,6 & $498,59 \pm 307,83$ \\
\hline Vitamin C (mg/hari) & 5,8 & 1393,6 & $146,13 \pm 186,53$ \\
\hline Moderasi (skor) & 3 & 24 & $12,73 \pm 3,66$ \\
\hline Total lemak (g/hari) & 20,8 & 156,9 & $75,37 \pm 28,42$ \\
\hline Lemak jenuh/SFA (g/hari) & 4,7 & 95 & $36,49 \pm 12,69$ \\
\hline Kolesterol (g/hari) & 26 & 921,9 & $266,05 \pm 173,52$ \\
\hline Natrium (mg/hari) & 94,5 & 4565,6 & $786,75 \pm 777,14$ \\
\hline Makanan rendah zat gizi ( $\%$ total energi) & 1 & 41 & $15,717 \pm 9,35$ \\
\hline Keseimbangan keseluruhan (skor) & 0 & 6 & $0,89 \pm 1,724$ \\
\hline Makronutrien & 0 & 6 & $0,8 \pm 1,682$ \\
\hline Asam lemak & 0 & 2 & $0,09 \pm 0,408$ \\
\hline PUFA (g/hari) & 2,4 & 34,8 & $12,11 \pm 6,92$ \\
\hline MUFA (g/hari) & 5,2 & 62 & $18,16 \pm 10,59$ \\
\hline Karbohidrat & 73,6 & 522,2 & $256,42 \pm 112,29$ \\
\hline
\end{tabular}

Komponen terakhir, yaitu keseimbangan keseluruhan yang terdiri atas proporsi sumber energi dan komposisi asam lemak. Dalam penelitian ini diketahui skor keseimbangan keseluruhan memiliki rerata $0,89 \pm 1,724$ yang menunjukkan rata-rata subjek memiliki skor keseimbangan keseluruhan yang tergolong rendah yang mencerminkan ketidakseimbangan diet, yaitu konsumsi makanan subjek sehari-hari memiliki proporsi yang kurang seimbang pada kelompok sumber energi dan komposisi asam lemak. Pada penelitian ini diketahui rasio asupan makronutrien subjek tidak seimbang dikarenakan subjek lebih banyak mengkonsumsi sumber lemak dibanding sumber makronutrien lainnya. Rasio asam lemak dalam penelitian ini diketahui tergolong tidak seimbang dikarenakan konsumsi bahan makanan sumber asam lemak jenuh yang tinggi.

\section{Hubungan Kualitas Diet dan Status KEK dengan Kadar Hemoglobin}

Uji regresi linear sederhana digunakan untuk analisis bivariat. Berdasarkan tabel 6 diketahui bahwa asupan protein, asupan zat besi,dan lingkar lengan atas berkorelasi positif dengan kadar hemoglobin dengan nilai $\mathrm{p}<0,05$, yang menunjukkan semakin rendah asupan protein dan zat besi makan semakin rendah kadar hemoglobin. Selain itu, semakin rendah lingkar lengan atas semakin rendah kadar hemoglobin subjek.
Tabel 6. Hubungan Kualitas Diet dan Status KEK dengan Kadar Hemoglobin

\begin{tabular}{lcc}
\hline \multicolumn{1}{c}{ Variabel } & $\boldsymbol{p}$ & $\mathbf{B}$ \\
\hline Kualitas diet & 0,37 & $-0,109$ \\
Variasi & 0,609 & $-0,062$ \\
Seluruh kelompok & 0,83 & $-0,026$ \\
Sumber protein & 0,587 & $-0,066$ \\
Kecukupan & 0,987 & 0,002 \\
Porsi sayur & 0,569 & 0,069 \\
Porsi buah & 0,422 & $-0,098$ \\
Posi makanan pokok & 0,092 & $-0,203$ \\
Serat & 0,544 & 0,544 \\
Protein & $\mathbf{0 , 0 0 7}$ & 0,322 \\
Zat besi & $\mathbf{0 , 0 0 9}$ & 0,309 \\
Kalsium & 0,429 & 0,096 \\
Vitamin C & 0,346 & 0,114 \\
Moderasi & 0,089 & $-0,205$ \\
Lemak total & 0,909 & 0,014 \\
Lemak jenuh/SFA & 0,425 & 0,097 \\
Kolesterol & 0,373 & 0,108 \\
Natrium & 0,422 & 0,097 \\
Makanan rendah zat gizi & 0,837 & 0,025 \\
Keseimbangan keseluruhan & 0,235 & $-0,144$ \\
Makronutrien & 0,279 & $-0,131$ \\
Asam lemak & 0,578 & $-0,068$ \\
Status KEK (Lingkar lengan & $\mathbf{0 , 0 1 8}$ & 0,283 \\
atas) & & \\
\hline & & \\
\hline
\end{tabular}




\section{PEMBAHASAN}

Wanita pra konsepsi diasumsikan sebagai wanita dewasa yang siap menjadi seorang ibu, dimana kebutuhan gizi pada masa ini berbeda dengan masa anakanak, remaja, ataupun lanjut usia. Kebutuhan zat gizi pada masa ini menjadi penting, karena wanita usia pra konsepsi merupakan kelompok wanita yang akan mempersiapkan kehamilan dan menyusui. Prakonsepsi merupakan periode kehidupan dimana terjadi perubahan fisik, psikologis, dan perilaku secara signnifikan. Periode ini juga merupakan periode yang rentan dalam kehidupan manusia terhadap perkembangan terjadinya anemia defisiensi zat gizi, yang sering diabaikan oleh masyarakat. Dalam keluarga ekonomi menengah kebawah, anak perempuan lebih cenderung dinomor duakan atau diabaikan. Mereka cenderung tidak mendapatkan asupan makanan dan pendidikan yang baik dan dimanfaatkan sebagai tenaga ekstra untuk melaksanakan pekerjaan rumah tangga. ${ }^{17}$

Dalam penelitian ini diketahui sebanyak 22 subjek berisiko mengalami Kurang Energi Kronis (KEK) dan terdapat 10 subjek yang mengalami Kurang Energi Kronis (KEK). Kurang Energi Kronis (KEK) biasanya terjadi pada masa remaja dan akan berlanjut ke masa selanjutnya jika tidak ditangani dengan baik. Kurang Energi Kronis (KEK) pada calon pengantin wanita akan menyebabkan masalah pada masa selanjutnya saat hamil dan menyusui. Pada masa kehamilan, wanita yang mengalami KEK dapat mengalami anemia, komplikasi pada masa kehamilan, pendarahan, dan mudah terserang penyakit infeksi. Pengaruh kurang energi kronis pada proses persalinan dapat mengakibatkan persalinan menjadi sulit dan lama, persalinan sebelum waktunya (prematur), dan persalinan melalui operasi. Ibu yang KEK akan berisiko tinggi mengalami keguguran, bayi lahir mati, cacat bawaan, anemia pada bayi, mati dalam kandungan, dan berat badan lahir rendah (BBLR). ${ }^{18,19}$

Calon pengantin wanita rentan menderita anemia defisiensi zat gizi terutama besi dan asam folat dikarenakan mengalami masalah yang dialami wanita usia subur, seperti mengalami menstruasi setiap bulannya yang kehilangan darah sekitar 0-48 mg per hari (tergantung pada aliran menstruasi), kurang asupan zat gizi, infeksi parasit seperti malaria, kecacingan serta mayoritas wanita usia subur menjadi angkatan kerja. ${ }^{3,5}$ Diagnosis anemia defisiensi zat gizi ditentukan dengan tes skrining melalui pengukuran kadar $\mathrm{Hb}$, Hematokrit $(\mathrm{Ht})$, volume sel darah merah (MCV), konsentrasi $\mathrm{Hb}$ dalam sel darah merah $(\mathrm{MCH})$ dengan batasan terendah $95 \%$ acuan. ${ }^{20}$

Menurut Walmsley et al. secara berurutan perubahan laboratoris pada defisiensi besi sebagai berikut: (1) penurunan simpanan besi, (2) penurunan feritin serum, (3) penurunan besi serum disertai meningkatnya transferin serum, (4) peningkatan Red cell
Distribution Width (RDW), (5) penurunan Mean Corpuscular Volume (MCV), dan terakhir (6) penurunan hemoglobin. ${ }^{36}$ Didasari keadaan cadangan besi, akan timbul defisiensi besi yang terdiri atas tiga tahap, dimulai dari tahap yang paling ringan yaitu tahap pralaten (iron depletion), kemudian tahap laten (iron deficient erythropoesis) dan tahap anemia defisiensi besi (iron deficiency anemia).

Hasil pengukuran menunjukkan, sebanyak 8 subjek $(11,4 \%)$ memiliki kadar hemoglobin yang rendah. Dari 8 subjek yang memiliki kadar $\mathrm{Hb}$ rendah, sebanyak 4 subjek (50\%) tergolong anemia mikrositik hipokromik. Anemia mikrositik biasanya merupakan konsekuensi dari anemia defisiensi besi. Anemia mikrositik ditandai oleh produksi sel darah merah yang lebih kecil dari normal. Ukuran kecil sel-sel ini disebabkan oleh penurunan produksi hemoglobin, unsur utama sel darah merah. Pada pemeriksaan darah, sel mikrositik dapat dikenali karena lebih kecil dari inti limfosit. Pada pemeriksaan ini keadaan hipokromia juga dapat diamati.

Penyebab anemia mikrositik diantaranya adalah kurangnya produksi globin, pengiriman zat besi yang terbatas ke kelompok heme hemoglobin, kurangnya pengiriman zat besi ke kelompok heme, dan cacat pada sintesis kelompok heme. Karena memiliki siklus hilangnya zat besi setiap bulan melalui menstruasi, wanita berisiko lebih besar mengalami defisiensi besi dibandingkan pria. Kehilangan zat besi pada wanita ratarata 1 hingga $3 \mathrm{mg}$ per hari, dan asupan makanan seringkali tidak memadai untuk mempertahankan keseimbangan zat besi. ${ }^{37}$

Data Riskesdas tahun 2013 menunjukkan prevalensi anemia di Indonesia masih cukup tinggi, anemia pada remaja wanita sebesar $26,50 \%$ dan pada wanita usia subur $26,9 \%$. Anemia memiliki dampak yang cukup signifikan pada fase sebelum atau selama kehamilan. Anemia dapat berkontribusi pada kematian ibu dan janin.Anemia sebelum atau selama kehamilan juga berdampak terhadap risiko kelahiran bayi dengan BBLR. Di Jawa Tengah presentase bayi dengan BBLR tahun 2006 sebesar 1,78\%. Pada tahun 2015 diketahui presentase kejadian BBLR di kabupaten Semarang sebesar $4,7 \% .^{8}$

Kualitas diet merupakan penilaian konsumsi makan untuk mendeskripsikan seberapa baik diet seseorang jika dibandingkan dengan rekomendasi diet. Diet yang sehat, seimbang, dan bergizi adalah diet yang dapat memenuhi kebutuhan secara individual untuk mencapai kesehatan yang optimal, dimana asupan makanan dan zat gizi dapat menjaga tubuh pada keadaan yang sehat tanpa mengalami kelebihan, yang dapat menyebabkan peningkatan berat badan atau keracunan akibat zat gizi yang berlebih. Diet kualitas tinggi ialah diet yang aman, higienis, dapat menunjang pertumbuhan dan perkembangan, dan mencegah terjadinya penyakit serta gangguan gizi dan kesehatan. ${ }^{31}$ Dalam penelitian ini 
diketahui skor kualitas diet sebanyak 55 subjek $(78,6 \%)$ tergolong rendah.

Kualitas diet dinilai menggunakan Diet Quality Index-International (DQI-I) yang berfokus pada empat aspek utama, terdiri dari variasi, kecukupan, moderasi (tidak berlebihan), dan keseimbangan. ${ }^{32}$ Aspek pertama, yaitu variasi dievaluasi dengan dua komponen, yaitu variasi keseluruhan dan variasi sumber protein. Komponen ini digunakan untuk memperkirakan asupan yang berasal dari sumber yang berbeda. Pada penelitian ini diketahui variasi keseluruhan dan variasi sumber protein sebagian besar subjek sudah tergolong baik yang menunjukkan bahwa subjek memiliki kebiasaan makan dengan sumber yang bervariasi.

Aspek kedua yaitu kecukupan digunakan untuk mengevaluasi asupan dari elemen diet yang seharusnya kebutuhannya tercukupi untuk menjamin healthy diet dan mencegah defisiesnsi zat gizi. ${ }^{32}$ Pada penilaian aspek kecukupan, diketahui bahwa kecukupan asupan kelompok sayuran $(84,2 \%)$, zat besi $(70 \%)$, dan kalsium $(65,7 \%)$ tergolong kurang. Meskipun dari aspek variasi sumber makanan sudah tergolong beragam, namun jumlah makanan yang dikonsumsi masih kurang dari kebutuhan harian sehingga kecukupan beberapa zat gizi masih kurang.

Sebanyak 59 subjek $(84,2 \%)$ memiliki kecukupan konsumsi kelompok sayuran yang tergolong kurang. Dalam penelitian ini didapatkan hasil bahwa tidak ada hubungan antara kecukupan konsumsi kelompok sayuran dengan kadar hemoglobin, namun penelitian sebelumnya menunjukkan hasil yang berbeda. Penelitian yang dilakukan di Ghana tahun 2008 pada wanita usia subur yang menemukan adanya hubungan konsumsi sayur dan buah $<5$ sajian/hari dengan kejadian anemia $(p<0,001) .{ }^{33}$ Konsumsi sayur dan buah berkaitan dengan pencegahan penyakit kronis tidak menular, salah satunya anemia, karena kandungan fitokimia pada buah dan sayur yang berperan penting dalam mengoptimalkan fungsi fisiologis dan mencegah perkembangan gejala metabolik. ${ }^{34}$

Kecukupan asupan zat besi sebanyak 49 subjek (70\%) juga tergolong kurang. Asupan zat besi diketahui juga berhubungan dengan kadar hemoglobin $(p=0,009)$. Zat besi merupakan komponen utama yang memegang peranan penting dalam pembentukan darah (homopoiesis), yaitu mensintesis hemoglobin. Apabila simpanan dan jumlah asupan zat besi kurang dari kebutuhan akan mengakibatkan ketidakseimbangan zat besi di dalam tubuh, akibatnya kadar hemoglobin menurun di bawah batas normal yang disebut anemia defisiensi besi. ${ }^{26}$

Aspek ketiga adalah moderasi (tidak berlebihan) digunakan untuk mengevaluasi asupan makanan dan gizi yang dihubungkan dengan penyakit kronik dan seharusnya dibatasi. ${ }^{32}$ Khususnya untuk total lemak, lemak jenuh, kolesterol, dan natrium yang dapat memberikan konstribusi terjadinya penyakit kronis. Sebanyak 53 subjek $(75,7 \%)$ mengkonsumsi lemak lebih dari kebutuhan dan sebanyak 60 subjek $(75,7 \%)$ mengkonsumsi lemak jenuh lebih dari kebutuhan harian. Dalam penelitian ini tidak ditemukan adanya hubungan antara tingginya konsumsi lemak dengan kadar hemoglobin. Namun, pada penelitian sebelumnya yang dilakukan di Taiwan tahun 2005-2008 menemukan hasil bahwa wanita usia subur yang mengkonsumsi tinggi lemak pada dietnya memiliki risiko 10,11 kali lebih besar untuk mengalami anemia. ${ }^{35}$ Konsumsi lemak berlebih berkaitan dengan perubahan metabolisme zat besi berkaitan dengan kadar hepsidin yang tidak normal. Selain itu, pada penelitian ini juga ditemukan bahwa sebanyak 48 subjek $(68,6 \%)$ mengkonsumsi makanan rendah kandungan zat gizi (empty calorie food). Komponen ini diperkirakan menyuplai energi pada beberapa orang dan memiliki densitas zat gizi yang rendah, yang mana hanya menyediakan energi tetapi tidak cukup zat gizi, seperti gula, minyak, dan alkohol. ${ }^{32}$

Aspek terakhir adalah keseimbangan keseluruhan (overall balance) yang dievaluasi berdasarkan proporsi asupan makronutrien (karbohidrat, protein, dan lemak) dan proporsi asam lemak (asam lemak jenuh, asam lemak tidak jenuh tunggal, dan asam lemak tidak jenuh ganda). Pada penelitian ini diketahui 54 subjek $(77,1 \%)$ memiliki ketidakseimbangan rasio makronutrien dan sebanyak 66 subjek $(94,3 \%)$ memiliki ketidakseimbangan rasio asam lemak. Beberapa literatur telah menegaskan tentang pentingnya keseimbangan energi yang berasal dari makronutrien yang berkontribusi dalam menyumbang kecukupan asupan energi. ${ }^{32}$ Proporsi konsumsi asam lemak jenuh diketahui lebih tinggi sehingga rasio asam lemak dalam penelitian ini tergolong tidak seimbang. Peningkatan asupan asam lemak jenuh berkaitan dengan peningkatan risiko penyakit kronis tidak menular. ${ }^{32}$ Ketidakseimbangan asupan makronutrien dan asam lemak menunjukkan konsep healthy diet belum terimplementasi dengan baik. Ketidakseimbangan asupan zat gizi dapat meningkatkan risiko terhadap penyakit kronik tidak menular, seperti anemia.

Berdasarkan analisis bivariat diketahui terdapat korelasi yang bermakna antara lingkar lengan atas dengan kadar hemoglobin $(p=0,018)$. Pengukuran lingkar lengan atas (LiLA) merupakan salah satu cara untuk mengetahui risiko kurang energi kronis pada calon pengantin wanita. Pengukuran ini dapat memberikan gambaran mengenai keadaan simpanan otot dan lapisan lemak bawah kulit.Pengukuran lingkar lengan atas (LiLA) adalah pengukuran yang sederhana untuk menilai adanya malnutrisi energi dan protein karena menggunakan massa otot yang merupakan indeks yang sensitif terhadap perubahan. Hasil penelitian ini sesuai dengan penelitian sebelumnya yang dilakukan di Pakistan pada tahun 2016 yang menemukan adanya 
korelasi positif antara lingkar lengan atas dengan kadar hemoglobin pada mahasiswa perempuan $(p<0,05$; $\mathrm{r}=0,14){ }^{21}$

Asupan protein juga diketahui berhubungan dengan kadar hemoglobin dengan nilai $p=0,007$. Protein berperan dalam pengangkutan zat besi ke dalam plasma dan seluruh bagian tubuh yang membutuhkan. Protein plasma transferin mengangkut besi ke sum-sum tulang untuk pembentukan hemoglobin baru. Sisa besi disimpan dalam bentuk feritin dan hemosiderin di dalam hati, sumsum tulang belakang, limfa dan otot. ${ }^{22}$ Selain berperan dalam transport besi, penyimpanan dan komponen hemoglobin, protein juga berperan dalam absorbsi besi. Asam-asam amino yang mempunyai gugus sulfur memiliki efek pemacu (meningkatkan penyerapan) karena gugus ini mengikat besi non heme. ${ }^{23}$ Asam amino dengan gugus sulfur (terutama sistein) dapat ditemukan pada produk hewani seperti daging, ikan dan unggas. Sulfur yang terdapat dalam protein hewani dapat mengubah besi non heme menjadi bentuk yang lebih mudah diserap. ${ }^{24}$ Penelitian yang dilakukan oleh Syatriani dan Aryani (2010) di Makasar, menyatakan ada hubungan yang positif antara asupan protein dengan kejadian anemia. Mereka menyatakan bahwa remaja yang kekurangan protein berisiko 3,48 kali lebih besar untuk mengalami anemia daripada remaja yang memiliki kecukupan konsumsi protein yang baik. ${ }^{25}$

\section{SIMPULAN DAN SARAN}

Asupan Protein dan asupan zat besi yang kurang dan rendahnya lingkar lengan (KEK) atas berhubungan dengan menurunnya kadar hemoglobin (anemia) pada pengantin wanita. Anemia pada masa prakonsepsi dapat mengakibatkan peningkatan risiko keguguran, kematian janin, kelahiran prematur, perdarahan serta kematian ibu dan bayi. Oleh karena itu, perlu dilakukan pemantauan kadar hemoglobin, asupan makanan harian dengan sumber bahan makanan yang beragam, dan pengukuran lingkar lengan atas secara berkala pada wanita usia subur pranikah.

\section{UCAPAN TERIMAKASIH}

Penelitian ini dibiayai oleh Hibah Riset Penerapan dan Pengembangan (RPP) Fakultas Kedokteran UNDIP Tahun 2018.

\section{DAFTAR PUSTAKA}

1. Depkes RI. Pedoman Penanggulangan Anemia Gizi Untuk Remaja Putri,Wanita Usia Subur dan Calon Pengantin. Jakarta: Depkes RI ; 2011.

2. Depkes. Profil Kesehatan Indonesia tahun 2014 [Internet]. 2015. Available from: http://www.depkes.go.id/resources/download/pusd atin/profil-kesehatan-indonesia/profil-kesehatanindonesia-2014.pdf

3. Aisah S, Sahar J. Pengaruh Edukasi Kelompok Sebaya Terhadap Perubahan Perilaku Pencegahan Anemia Besi pada Wanita Usia Subur Di Kota Semarang. J Unimus. 2010;2:35-44.

4. Asyumdah. Gambaran Faktor-faktor Risiko BBLR Di Puskesmas Sumowono, Kabupaten Semarang [Tesis]. Stikes Ngudi Waluyo. 2016;

5. Balarajan Y, Ozaltin E, Shankar A, Subramanian S. Anaemia in low-income and middle-income countries. Dep Glob Heal an Popul. 2011;

6. Dinkes. Profil Kesehatan Provinsi Jawa Tengah Tahun 2014 [Internet]. Semarang; 2014. Available from:

http://www.dinkesjatengprov.go.id/v2015/dokume n/profil2014/Profil_2014.pdf

7. Dinas Kesehatan kota Semarang. Profil Kesehatan Kota Semarang 2014 [Internet]. Semarang; 2015. Available from: http://www.depkes.go.id/resources/download/profi 1/PROFIL KAB KOTA 2014/3374 Jateng Kota Semarang 2014.pdf

8. Dinas Kesehatan kabupaten Semarang. Profil Kesehatan Kabupaten Semarang 2015. Semarang; 2015.

9. Djamil A. Peraturan Direktur Jendral Bimbingan Masyarakat Islam Nomor:DJ.II/542. 2013.

10. Kesehatan K. Kesehatan Reproduksi dan Seksual bagi Calon Pengantin. Jakarta; 2015.

11. WHO. Hemoglobin Concentrations For the Diagnosis Of Anaemia and Assesment Of Severity. 2011;

12. Dinkes. Profil Kesehatan Kabupaten Semarang [Internet]. 2014. Available from: http://www.semarangkab.go.id/skpd/dinkes/

13. Kemenkes RI. Pedoman Interpretasi Data Klinik. Kemenkes RI; 2011.

14. Indonesia R. Pedoman Perencanaan Program Gerakan Sadar Gizi Dalam Rangka Seribu Hari Pertama Kehidupan (1000 HPK). Jakarta; 2012.

15. Rahman DR, M.Thaha AR, Syam A. Asupan gizi mikro terhadap kepatuhan konsumsi di Kota Makassar [Tesis]. Program Studi Ilmu Gizi Fakultas Kesehatan Masyarakat Universitas Hasanuddin; 2013.

16. Santals, A et all. Body Mass Index ad Chronic Energy Deficiecny among Adult Santals of Purulina Distrit, West Bengal, India.2010Jurnal correlation between.....

17. Rahmi L. Faktor-Faktor yang Berhubungan Dengan Kekurangan Energi Kronik (KEK) pada Ibu Hamil di Puskesmas Belimbing Padang. J Kesehat Med Saintika. 2016;8:35-46.

18. Ariyani DE, Achadi EL, Irawati A. Validitas Lingkar Lengan Atas Mendeteksi Risiko 
Kekurangan Energi Kronis pada Wanita Indonesia. Kesmas Natl Public Heal J. 2012;7(2):83-90.

19. Marizal. Anemia Defisiensi Besi. J Kesehat Masy. 2007;2.

20. Soekirman. Ilmu Gizi dan Aplikasinya Untuk Keluarga dan Masyarakat. Jakarta: Departemen Pendidikan Nasional; 2000.

21. Laghari ZA, et al. Correlation of BMI and MUAC with Anemia among Sindh University Students, Jamshoro, Pakistan. Sindh Univ Res Jour. 2017: 49 (3): 553-556.

22. J.Corwin E. Buku Saku Patofisiologi. 3 ed. Jakarta: Penerbit Buku Kedokteran EGC; 2007.

23. Kathleen L, Escott-Stum S. Krause's, Food and Nutrition Therapy. Saunders Elsevier. 2008. 865$872 \mathrm{p}$.

24. Murray R, W.Rodwell V. Biokimia Harper. 27th Ed. Jakarta: Penerbit Buku Kedokteran; 2009.

25. S S, Aryani. Konsumsi Makanan dan Kejadian Anemia pada Siswi Salah Satu SMP di Kota Makassar. J Kesehat Masy Nas. 2010;4.

26. Qin Y, Melse-Boonstra A, Xiaoqun Pan, YuanB, Dai Y, Zhao J, Zimmermann MB, Kok FJ, Xzhao M \& Shi Z, Anemia inrelation to body mass index and wais circumeference among Chinese women. $\mathrm{J}$ Nutr 12: 2013: 10.

27. Kamruzzaman, Rabbani G, Saw A, Sayem A \& Hossain G, Differentials inthe prevalence of anemia among nonpregnant,ever-married women in Bangladesh: multilevel logistic regressionanalysis of data from the 2011 BangladeshDemographic and Health Survey. BMCWomen's Health; 2015.

28. Gupta A, Parashar A, Thakur A \& Sharma D, Anemia among adolescent girls inShimla hills of
North India: Does BMI andonset of menarche have a role? Indian J MedSci; 2012; 66(5): 126-130.

29. Neggers $Y$ \& Goldenberg RL, Somethoughts on body mass index, micronutrientintake and pregnancy outcome. Am J ClinNutr; 2003; 133: 1737S-1740S

30. Black RE, Allen LH, Bhutta ZA, Caufield LE,De Onis M, Ezzati M, Rivera J, Maternal and child under nutrition: Global and regional exposures andhealth consequences. The Lancet Serieson Maternal and Child Undernutrition 1.Lancet, 2008; doi:10.1016/S0140-6736(07)61690-0.

31. Alkerwi A. Diet Quality Concept. J Nutr; 2013 (30).

32. Dieny, FF. 2014. Permasalahan Gizi pada Remaja Putri. Yogyakarta: Graha Ilmu.

33. Ghose and Yaya. 2018. Fruit and vegetable consumption and anemia among adult non-pregnant women: Ghana Demographic and Health Survey. PeerJ 6:e4414; DOI 10.7717/peerj.4414

34. Syed S, Yaw Addo O. 2016. Determinants of Anemia among School-Aged Children in Mexico, the United States and Colombia. Nutrients 8(7):387 DOI 10.3390/nu8070387

35. Chang, J.-S., Chen, Y.-C., Owaga, E., Palupi, K. C., Pan, W.-H., \& Bai, C.-H. 2014. Interactive Effects of Dietary Fat/Carbohydrate Ratio and Body Mass Index on Iron Deficiency Anemia among Taiwanese Women. Nutrients, 6(9), 3929-3941. http://doi.org/10.3390/nu6093929

36. Walmsley, R.N., Watkinson LR., Cain HJ., 1999, Plasma Iron: Case in chemical pathology a diagnostic approach, 4 th edition, 46.-238.

37. DeLoughery TG. Microcytic Anemia. New England Journal of Medicine 2014; 371:1324-31. 